\title{
Molecular Analysis of Uroporphyrinogen Decarboxylase Deficiency in a Family with Two Cases of Hepatoerythropoietic Porphyria
}

\author{
Hubert de Verneuil, Bernard Grandchamp, Paul H. Romeo, Natacha Raich, Carole Beaumont, \\ Michel Goossens, Henriette Nicolas, and Yves Nordmann \\ Department of Biochemistry, Faculty of Medicine X. Bichat, Hospital Louis Mourier, Colombes, France; Institut National de la Santé et \\ de la Recherche Médicale U.91 and Service de Biochimie, Hospital Henri Mondor, Créteil, France; Institut National de la Santé et \\ de la Recherche Médicale U.73, Paris, France
}

\begin{abstract}
In order to determine the molecular basis of uroporphyrinogen (URO) decarboxylase deficiency responsible for hepatoerythropoietic porphyria (HEP) and familial porphyria cutanea tarda, we used a human URO decarboxylase cDNA to analyze the organization and expression of the URO decarboxylase gene in lymphoblastoid cells from normal individuals and from two patients with HEP. We could detect neither deletions nor rearrangements in the URO decarboxylase gene. Synthesis, processing, and cell-free translation of the specific transcripts appeared to be normal. The half-life of the abnormal protein was 12 times shorter than that of the normal enzyme. The results indicate that the enzyme defect is due to a rapid degradation of the protein in vivo. This study is the first to provide information regarding the molecular mechanism responsible for the URO decarboxylase deficiency in HEP.
\end{abstract}

\section{Introduction}

Uroporphyrinogen (URO) ${ }^{1}$ decarboxylase (E.C. 4.1.1.31) is a cytosolic enzyme which catalyzes the sequential removal of the four carboxyl groups of the carboxymethyl side chains in uroporphyrinogen to yield coproporphyrinogen (1). The enzyme has been purified from different sources (2-5) and antibodies have been obtained against the enzyme. URO decarboxylase deficiency results in the clinical disorders of porphyria cutanea tarda (PCT) and hepatoerythropoietic porphyria (HEP). PCT is characterized clinically by blister formation, increased skin fragility, hypertrichosis, pigmentary changes, and sclerodermoid plaques (1). The familial form, or type II, of PCT is characterized by a dominantly inherited deficiency of the enzyme activity (6-8); this deficiency has been documented in all cell types investigated (1). HEP (9) is a severe form of cutaneous porphyria that occurs very early in infancy and is characterized clinically by photosensitivity, bullae, erosions, hypertrichosis, and redcolored urine. The enzymatic deficiency responsible for the disease is much more severe than in familial PCT. It has been postulated that patients with HEP may be homozygous for the

Address reprint requests to Dr. Nordmann, Department of Biochemistry, Hospital Louis Mourier, Colombes 92701, France.

Received for publication 31 July 1985.

1. Abbreviations used in this paper: HEP, hepatoerythropoietic porphyria; PCT, porphyria cutanea tarda; URO, uroporphyrinogen.

J. Clin. Invest.

(c) The American Society for Clinical Investigation, Inc.

0021-9738/86/02/0431/05 \$1.00

Volume 77, February 1986, 431-435 gene that causes familial PCT in the heterozygous state (10-12). However, the situation may be more complicated, since, as in many other genetic diseases, the same clinical syndrome can correspond to different molecular lesions in different families. Therefore, further understanding of the relationship between various conditions associated with a URO decarboxylase defect requires a molecular analysis of the mutation leading to the enzymatic deficiency.

In most cases of familial PCT investigated, immunological and catalytic assays have suggested that the mutation does not lead to the accumulation of a catalytically inactive gene product $(11,13)$. We obtained the same result in our recent study of two HEP patients (11). These results indicate either that the URO decarboxylase deficiency is due to a defect in the expression of the gene (gene deletion, defective transcription, abnormal processing of the mRNA, unstable or untranslatable mRNA) or that the protein coded for by the mutant gene is unstable in vivo. In familial PCT, as in most of the other dominantly transmitted porphyrias, the characterization of the molecular defect is complicated by the presence of a normal gene coexisting with the mutant allele. In this report we studied a family where the homozygous patients are products of consanguineous parents. The availability of a human URO decarboxylase cDNA clone allowed us to investigate the mutant gene and its expression in lymphoblastoid cell lines.

\section{Methods}

Case report. Subjects consisted of two patients ( 1 and 2 ) with hepatoerythropoietic porphyria who have been previously described (11). URO decarboxylase activity was measured in the $12,000 \mathrm{~g}$ supernatant of homogenized lymphoblastoid cells with a previously described method modified for use on a smaller scale (14). The enzymatic defect was identical to that found in the erythrocytes of the patients (11).

Establishment and maintenance of lymphoblastoid cell lines. Blood samples (10-20 ml) from the patients, both parents, and controls were anticoagulated with heparin. The lymphocytes were isolated by centrifugation in a Ficoll gradient and transformed with the Epstein-Barr virus. Each lymphoblast culture was maintained in RPMI 1640 medium supplemented with $20 \%$ fetal calf serum and $2 \mathrm{mM}$ glutamine at $37^{\circ} \mathrm{C}$ in the presence of $5 \% \mathrm{CO}_{2}$.

$R N A$ and DNA analyses. DNA was isolated either from leukocytes or from lymphoblast cells as previously described (15). $10 \mu \mathrm{g}$ of genomic DNA were digested with an excess of restriction enzyme. The resulting DNA fragments were fractionated on a $0.8 \%$ agarose gel and transferred onto nitrocellulose filter papers. Total cellular RNA was prepared from lymphoblast cells as described by Adrian and Hutton (method I) (16). RNA electrophoresis was performed in $1 \%$ agarose, $2.2 \mathrm{M}$ formaldehyde as described (17) and electrophoretic transfer to Zeta-probe was carried out according to the protocol of the manufacturer (Bio-Rad Laboratories, Richmond, CA). Filters were hybridized to a nick-translated ${ }^{32} \mathrm{P}$-labeled DNA probe made from a human cDNA insert of URO decarboxylase obtained from a human anemic spleen (Roméo, P. H., N. Raich, A. 
Dubart, D. Beaupain, M. Pryor, J. Kushner, M. Cohen-Solal, and M. Goossens, manuscript submitted for publication).

Antibody preparation. The preparation of anti-human uroporphyrinogen decarboxylase antibodies has been previously described (2).

Cell free translation. Total cellular RNA was denatured at $65^{\circ} \mathrm{C}$ for $5 \mathrm{~min}$, then rapidly cooled on ice and translated in a micrococcal nucleasetreated rabbit reticulocyte lysate system (18). Immunoprecipitations were carried out according to Omary et al. (19). Translation products were analyzed by sodium dodecyl sulfate-polyacrylamide gel electrophoresis according to Laemmli (20). The gel was treated with Amplify (Amersham Corp., Arlington Heights, IL), dried, and autoradiographed (5 d).

In vivo incorporation of $\left[{ }^{35} S\right]$ methionine into protein. Metabolic labeling of cells with $\left[{ }^{35} \mathrm{~S}\right]$ methionine was carried out in methionine-free RPMI 1640 medium containing 10\% fetal calf serum. After $2 \mathrm{~h}$ of pulse labeling, cells were washed twice using RPMI 1640 medium supplemented with $20 \%$ fetal calf serum and $2 \mathrm{mM}$ glutamine, then incubated in the same medium for various periods of time. Cells were lysed and the labeled URO decarboxylase was immunoprecipitated as described for cell-free translation.

\section{Results}

Blot hybridization of DNA (Southern blot). DNA from one normal subject and DNA from patient 1 (homozygous for the URO decarboxylase defect) were compared by restriction mapping using a full-length human cDNA as the hybridization probe (Fig. 1). The presence of a unique gene in the human DNA is very likely because of the simple pattern of restriction fragments obtained with different enzymes: two restriction fragments are obtained only when the restriction site is present in the cDNA. The probe hybridized to the same restriction fragments in DNA isolated from a normal cell line or from the two patients (only one is shown). This analysis failed to detect any large deletion or rearrangements in the mutant gene.

Blot hybridization of RNA (Northern and dot blots). The presence of the mRNA encoding URO decarboxylase was also studied by hybridization methods. Analyses of lines (one from the homozygous patient 1 and the other from one parent) shown in Fig. 2 (upper part) produced in each case a single radioactive band that indicated the presence of mRNA for URO decarboxylase. In both cases the mRNA migrated with a retardation factor similar to the control cells; it was 1,400 bases in length, in accordance with the previously determined size of the human URO decarboxylase mRNA (21). We performed dot-hybridization between cellular RNA and the specific probe to quantitate the relative amount of specific mRNA compared to the controls (Fig. 2, lower part). The results clearly demonstrate that the concentration of specific mRNA is very similar in the different cell lines tested.

Characterization of the translation products of URO decarboxylase mRNAs in normal and mutant cell lines. The presence of the mRNA in URO decarboxylase-deficient cell lines led us to compare in vitro translation products of URO decarboxylase mRNA both by relative amounts and by molecular size of the protein synthesized. The translated products were analyzed by sodium dodecyl sulfate-polyacrylamide gel electrophoresis after immunoprecipitation with URO decarboxylase antiserum (Fig. 3).

The same amount of neosynthesized URO decarboxylase was found between the normal (Fig. 3, lane 3) and the two deficient cell lines (Fig. 3, lane 5 for patient 1, data not shown for patient 2). The size of the protein was determined by comparing the migration of the immunoprecipitated newly synthesized URO decarboxylase to the migrations of the purified ${ }^{14} \mathrm{C}$-labeled

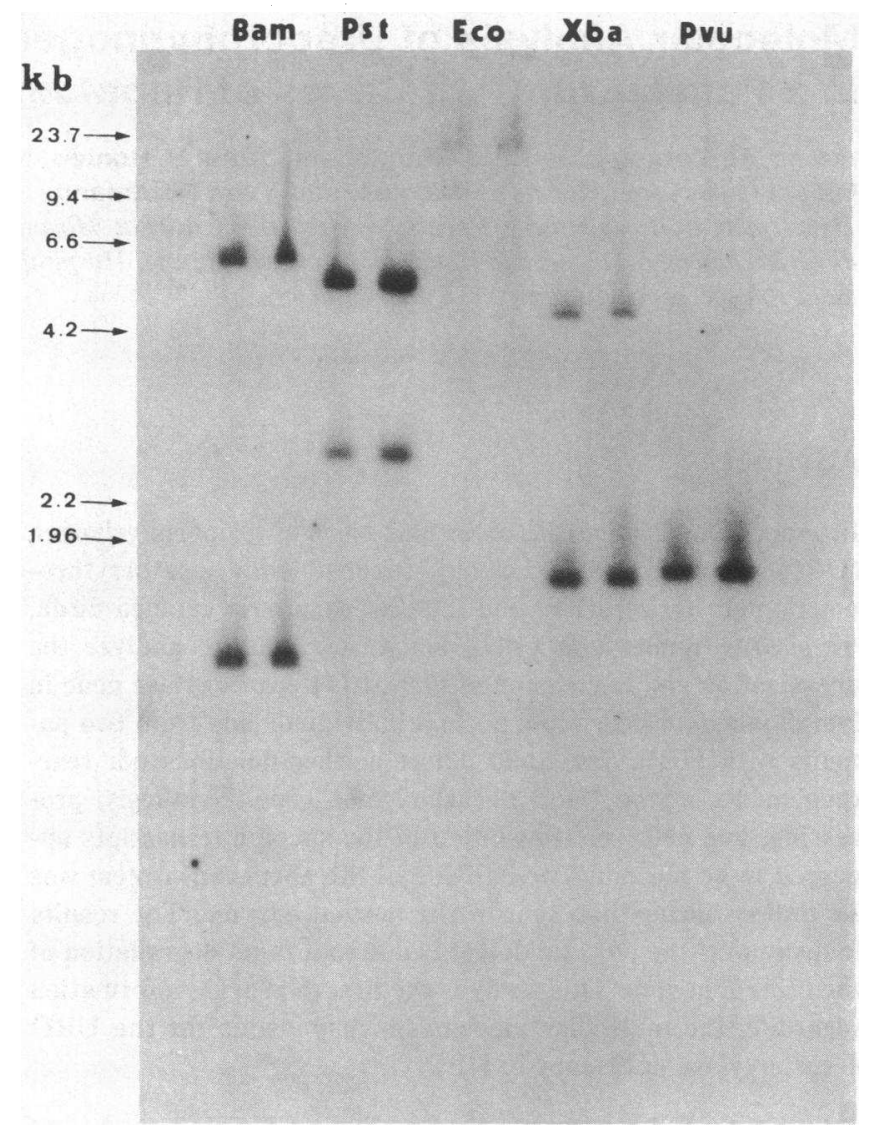

Figure 1. Autoradiograph of a blot hybridization of human genomic DNA from normal (left) and deficient (patient 1, right) lymphoblast cell lines. Genomic DNA $(10 \mu \mathrm{g})$ was digested with restriction endonuclease (Bam HI, Pst I, Eco RI, Xba I, and Pvu II) and electrophoresed in $0.8 \%$ agarose gel. The DNA was transferred to nitrocellulose paper and hybridized at $42^{\circ} \mathrm{C}$ in $50 \%$ formamide for $24 \mathrm{~h}$ with nicktranslated [ $\left.{ }^{32} \mathrm{P}\right] \mathrm{cDNA}\left(10^{6} \mathrm{cpm} / \mathrm{ml}, 2 \times 10^{8} \mathrm{cpm} / \mu \mathrm{g}\right)(17)$. Arrows at the left margin indicate the position of DNA markers (DNA cut by Hind III).

human enzyme and of other standard proteins on polyacrylamide gels. The molecular weight of the different products was identical to that of the marker enzyme (Fig. 3, lanes 3 and 5, compared to lane 2).

Turnover rate of $\left[{ }^{35} S\right]$ methionine-labeled URO decarboxylase. The results reported above suggest that the mRNA encoding the abnormal enzyme is functional. However, the protein is present at a low level (5\% of control value) (6). We then performed labeling experiments on lymphoblastoid cell lines to measure the half-life of the enzyme. As shown in Fig. 4, pulsechase experiments with $\left[{ }^{35} \mathrm{~S}\right]$ methionine-labeled protein demonstrate that the normal enzyme is relatively stable and is degraded with $t^{1 / 2}$ of $\sim 82 \mathrm{~h}$. In contrast, the abnormal enzyme from the two patients appears to turn over more rapidly: $85 \%$ of the labeled protein is lost within $20 \mathrm{~h}\left(\mathrm{t}^{\mathrm{t} / 2}, \sim 7 \mathrm{~h}\right)$.

\section{Discussion}

The results reported in this paper provide the first details as to the molecular mechanism responsible for the URO decarboxylase deficiency in HEP. The two patients presented with a de- 

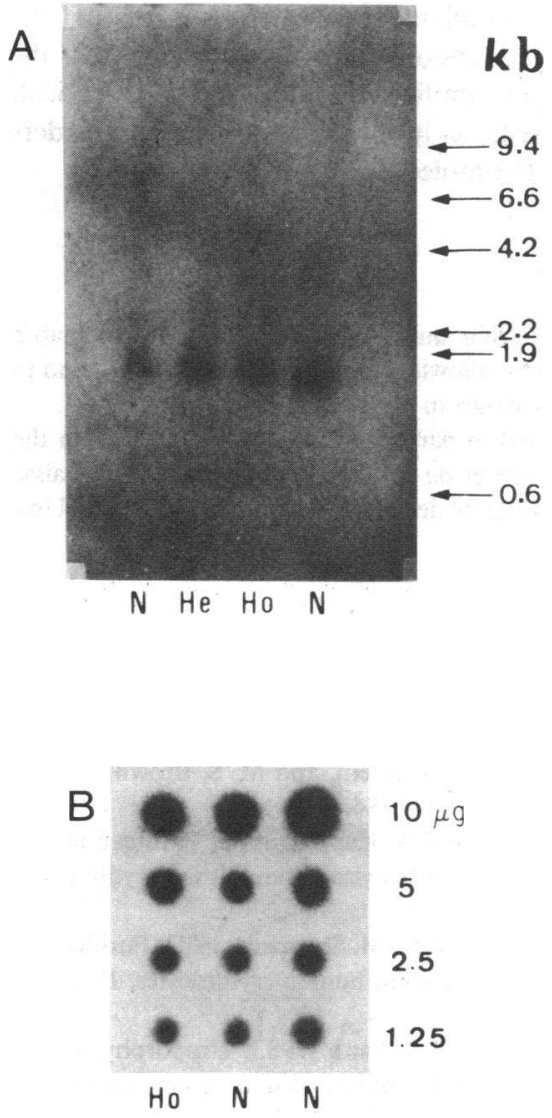

Figure 2. (A) Autoradiograph of a blot hybridization of RNA from normal and deficient lymphoblast cell lines (patient 1). Total RNA (20 $\mu \mathrm{g})$ from two controls $(\mathrm{N})$, one parental $(\mathrm{He})$, and one homozygous deficient cell line (Ho) was denatured and applied to a $1 \%$ agarose gel containing $2.2 \mathrm{M}$ formaldehyde for electrophoresis. The RNA was transferred electrophoretically to a Zeta-probe membrane, hybridized for $16 \mathrm{~h}$ at $42^{\circ} \mathrm{C}$ with nick-translated [ $\left.{ }^{32} \mathrm{P}\right] \mathrm{cDNA}\left(10^{6} \mathrm{cpm} / \mathrm{ml}, 1.5\right.$ $\times 10^{8} \mathrm{cpm} / \mu \mathrm{g}$ ) in the presence of $50 \%$ formamide and $10 \%$ dextran sulfate and washed at stringent conditions (to $0.1 \times$ saline sodium citrate at $\left.60^{\circ} \mathrm{C}\right)$. (B) Autoradiograph of dot hybridization of RNA from normal $(\mathrm{N})$ and deficient (Ho) lymphoblast cell lines. $10 \mu \mathrm{g}$ of total RNA and serial dilutions were spotted on a Zeta-probe membrane, hybridized, and washed as described for the Northern blot.

creased URO decarboxylase activity (5\% of the normal values) in red blood cells and lymphoblastoid cell lines. The parents of the patients were second cousins and both of them had a defect of URO decarboxylase activity (30 and $34 \%$ of the mean normal value for the father and mother, respectively). These data are consistent with the hypothesis that the patients are homozygous and their parents heterozygous for the same gene defect. The immunological measurement of URO decarboxylase in red blood cells from the patients and their parents indicated that the immunoreactive protein was decreased to a similar extent as its enzymatic activity (11).

The genetic lesion in HEP has its metabolic expression mainly in erythrocytes and liver cells; it remains possible that there is a difference in gene expression in different tissues. However, the enzymatic deficiency has been found in all tissues investigated (erythrocytes, lymphocytes, and fibroblasts), and therefore, it is reasonable to assess the functional consequences

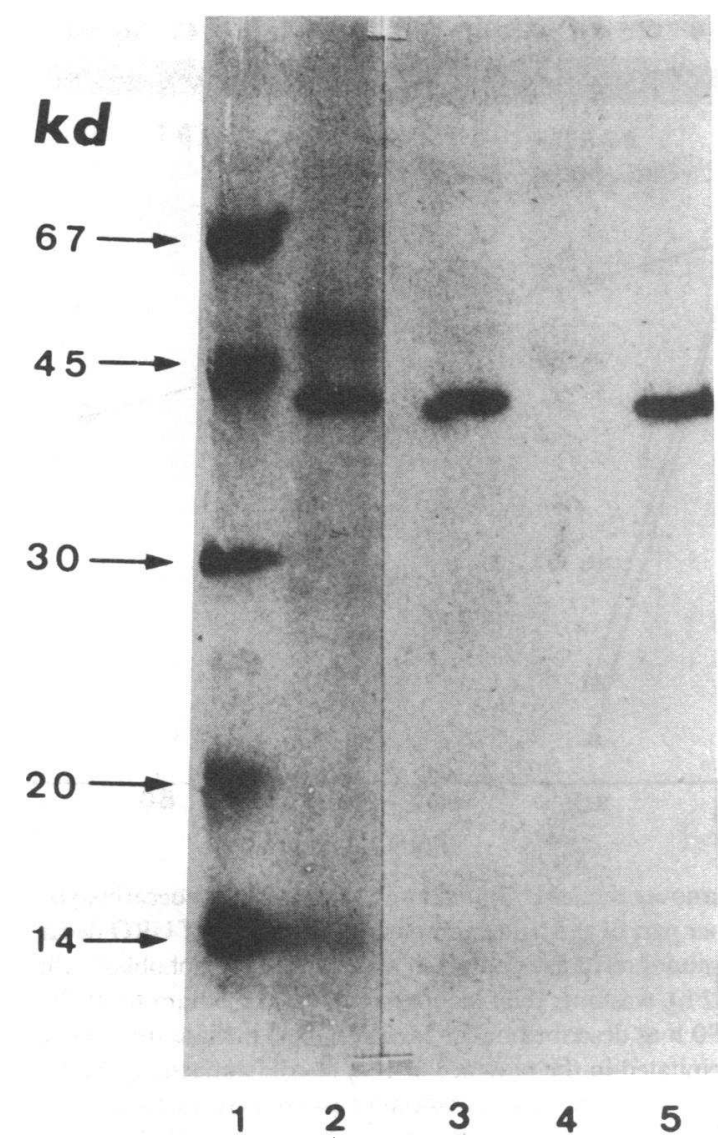

Figure 3. Autoradiograph of a sodium dodecyl sulfate-polyacrylamide gel electrophoresis of proteins translated in vitro and specifically immunoprecipitated by a human URO decarboxylase antibody. Cell-free synthesis was performed in a total reaction mixture of $100 \mu l$, containing $25 \mu \mathrm{g}$ of total RNA from the cell lines. Radioactivity incorporated into trichloroacetic precipitable material was about $2.5 \times 10^{6} \mathrm{cpm}$. Labeled translation products $(800,000 \mathrm{cpm})$ were immunoprecipitated with $1 \mu \mathrm{l}$ of antiserum and applied to the electrophoresis gel. Lane 1 , ${ }^{14} \mathrm{C}$-labeled protein markers: bovine serum albumin (relative molecular weight $\left.\left[M_{\mathrm{r}}\right]=67,000\right)$; ovalbumin $\left(M_{\mathrm{r}}=45,000\right)$; carbonic anhydrase $\left(M_{\mathrm{r}}=30,000\right)$; soybean trypsin inhibitor $\left(M_{\mathrm{r}}=20,100\right)$; lactalbumin $\left(M_{\mathrm{r}}=14,400\right)$. Lane $2,{ }^{14} \mathrm{C}$-labeled URO decarboxylase purified from human erythrocytes. Lane 3, ${ }^{35}$ S $]$ URO decarboxylase neosynthesized with RNA from a normal cell line. Lane 4, same as lane 3, but in the presence of $1 \mu \mathrm{g}$ of cold URO decarboxylase at the immunoprecipitation step. Lane $5,\left[{ }^{35}\right.$ S $]$ URO decarboxylase neosynthesized with RNA from a homozygous-deficient cell line (patient 1).

of the gene abnormality using lymphoblastoid cell lines from patients.

Northern and dot blot analysis indicated the presence of URO decarboxylase-specific transcripts of normal size and in equal amounts as compared with the control lines. The URO decarboxylase gene is transcribed and the transcript is normally processed leading to the presence of messenger RNA in patients' cells. The enzymatic deficiency could be due to a defect in the translation of the message or to a rapid degradation of the $a b-$ normal protein in vivo. Analysis of the cell-free translation products directed by mRNA from patient cells clearly eliminated the first hypothesis; a normal amount of immunoprecipitable URO decarboxylase was synthesized in vitro. In contrast, estimation of the URO decarboxylase turnover in lymphoblastoid 

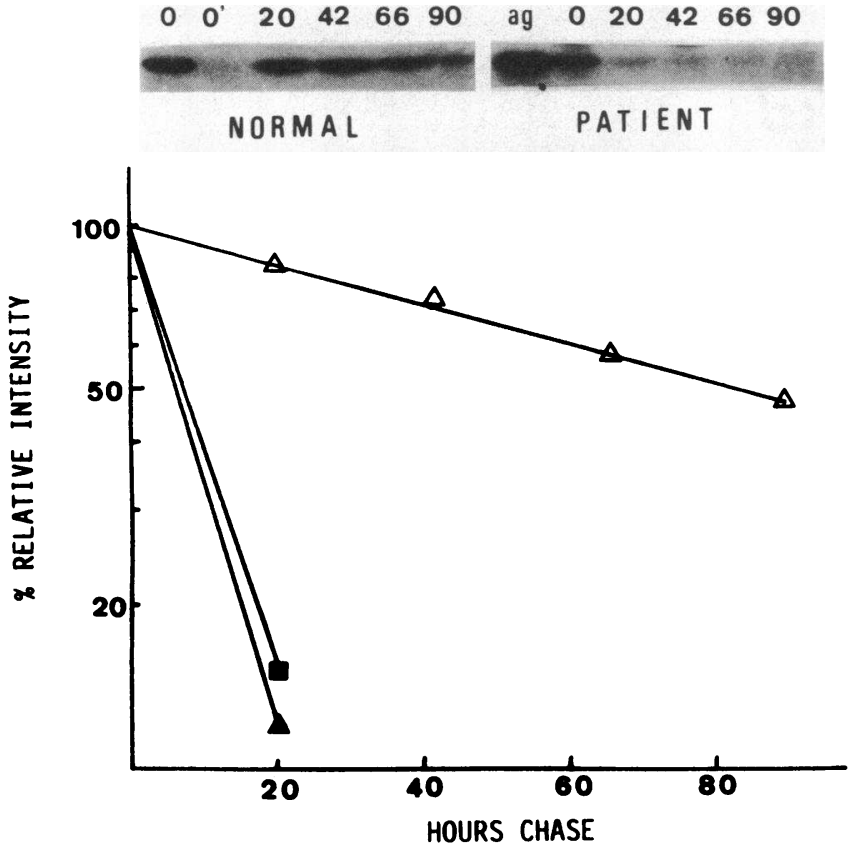

Figure 4. Turnover rate of $\left[{ }^{35} \mathrm{~S}\right]$ methionine-labeled URO decarboxylase. The upper part of the figure shows autoradiograms of URO decarboxylase immunoprecipitates obtained after labeling lymphoblast cells $(30 \mu \mathrm{Ci} / \mathrm{ml}, 2 \mathrm{~h}$ ), washing, then incubating in usual medium for 0,20 , 42,66 , and $90 \mathrm{~h}$ as described under Methods $\left(0^{\prime}: 0 \mathrm{~h}\right.$ chase time point immunoprecipitated in the presence of $1 \mu \mathrm{g}$ of cold antigen; ag: pure ${ }^{14} \mathrm{C}$-labeled URO decarboxylase). Autoradiograms were scanned and a semilog plot is shown (in the lower part) for the percentage of integrated values (relative to the $0 \mathrm{~h}$ chase time point) vs. hours of chase. $4 \times 10^{6} \mathrm{cpm}$ of trichloracetic precipitable material were used for each point. $37-43 \%$ of the trichloracetic precipitable material remained after $90 \mathrm{~h}$ in chase medium for the different experiments. $\Delta$, normal cell line; $\mathbf{a}$, patient 1 cell line; $\Delta$, patient 2 cell line.

cell lines from patients revealed that the half-life of the protein was about 12 times shorter as compared with that of URO decarboxylase in cell lines from controls. From these results we can assume that the enzyme defect in this family is accounted for by a great instability and a rapid degradation of the protein in vivo. This is likely to be due to a point mutation in the encoding part of the gene leading to the substitution of an amino acid in the protein. However, our results do not rule out the possibility of an abnormal posttranslation modification of the protein in the patients. Cloning of a cDNA complementary to URO decarboxylase mRNA from patients and sequencing of this cDNA should definitively confirm the point mutation hypothesis.

The type of abnormality described here is very similar to that found in other inherited enzymatic defects, where the most common types of mutation lead to the formation of an unstable protein or a protein with altered immunological and catalytic properties $(16,22-24)$. Most of the inherited diseases studied at the molecular level are X-linked or autosomal recessive (25). For an autosomal dominant disease, the characterization of the molecular defect is complicated by the presence of a normal copy of the gene. Since there is a possibility that HEP represents a homozygous form of familial PCT (10-12), the characterization of the mutant gene responsible for HEP in homozygous patients may be an approach to the study of familial PCT. The use of oligonucleotide probes complementary to the normal and the mutant sequences (26-27) should allow us to determine if the mutations responsible for familial PCT and HEP are identical, or if a heterogeneity exists, as in most of the genetic disorders already investigated at the molecular level.

\section{Acknowledgments}

We are indebted to Dr. Z. Sfar and Dr. R. Kastally (Hopital Habib Thameur, Tunis, Tunisia) for allowing us to study their patients, and to Mrs. C. Guyomard for assistance in preparing the manuscript.

This work was supported in part by grant CRE 83.10.12 from the Institut National de la Santé et de la Recherche Médicale, by Caisse Nationale de l'Assurance Maladie des Travailleurs Salariés, and by University Paris 7 .

\section{References}

1. Kappas, A., S. Sassa, and K. E. Anderson. 1983. The porphyrias. In The Metabolic Basis of Inherited Disease. J. B. Stanbury, J. B. Wyngaarden, D. S. Fredrickson, J. L. Goldstein, and M. S. Brown, editors. McGraw Hill Inc., New York. 1301-1384.

2. de Verneuil, H., S. Sassa, and A. Kappas. 1983. Purification and properties of uroporphyrinogen decarboxylase from human erythrocytes. J. Biol. Chem. 258:2454-2460.

3. Elder, G. H., J. A. Tovey, and D. M. Sheppard. 1983. Purification of uroporphyrinogen decarboxylase from human erythrocytes. Biochem. J. 215:45-55.

4. Kawanishi, S., Y. Seki, and S. Sano. 1983. Uroporphyrinogen decarboxylase. Purification, properties and inhibition by polychlorinated biphenyl isomers. J. Biol. Chem. 258:4285-4292.

5. Straka, J. G., and J. P. Kushner. 1983. Purification and characterization of bovine hepatic uroporphyrinogen decarboxylase. Biochemistry. 22:4664-4672.

6. de Verneuil, H., G. Aitken, and Y. Nordmann. 1978. Familial and sporadic porphyria cutanea. Two different diseases. Hum. Genet. 44:145-151.

7. Elder, G. H., G. B. Lee, and J. A. Tovey. 1978. Decreased activity of hepatic uroporphyrinogen decarboxylase in sporadic porphyria cutanea tarda. N. Engl. J. Med. 299:274-278.

8. Kushner, J. P., A. J. Barbuto, and G. R. Lee. 1976. An inherited enzymatic defect in porphyria cutanea tarda. Decreased uroporphyrinogen decarboxylase activity. J. Clin. Invest. 58:1089-1097.

9. Pinol Aguade, J., A. Castells, A. Indacochea, and J. Rodes. 1969. A case of biochemically unclassifiable hepatic porphyria. Br. J. Dermatol. 81:270-275.

10. Elder, G. H., S. G. Smith, C. Herrero, M. Lecha, J. M. Mascaro, A. M. Muniesa, D. B. Czornecki, J. Brenau, V. Poulos, and R. E. de Salamanca. 1981. Hepato-erythropoietic porphyria: a new uroporphyrinogen decarboxylase defect or homozygous porphyria cutanea tarda. Lancet. i:916-919.

11. de Verneuil, H., C. Beaumont, J. C. Deybach, Y. Nordmann, Z. Sfar, and R. Kastally. 1984. Enzymatic and immunological studies of uroporphyrinogen decarboxylase in familial porphyria cutanea tarda and hepatoerythropoietic porphyria. Am. J. Hum. Genet. 36:613-622.

12. Lazaro, P., R. E. De Salamanca, G. H. Elder, M. L. Villaseca, S. Schinarro, and G. Jaqueti. 1984. Is hepatoerythropoietic porphyria a homozygous form of porphyria cutanea tarda? Br. J. Dermatol. 110:613-617.

13. Elder, G. H., D. M. Sheppard, J. A. Tovey, and A. J. Urquhart. 1983. Immunoreactive uroporphyrinogen decarboxylase in porphyria cutanea tarda. Lancet. i:1301-1303.

14. de Verneuil, H., S. Sassa, and A. Kappas. 1983. Effects of polychlorinated biphenyl compounds, 2,3,7,8-tetrachlorodibenzo-dioxin, phenobarbital and iron on hepatic uroporphyrinogen decarboxylase. Biochem. J. 214:145-151. 
15. Goossens, M., and Y. W. Kan. 1981. DNA analysis in the diagnosis of hemoglobin disorders. Methods Enzymol. 76:805-817.

16. Adrian, G. S., and J. J. Hutton. 1983. Adenosine deaminase messenger RNAs in lymphoblast cell lines derived from leukemic patients and patients with hereditary adenosine deaminase deficiency. J. Clin. Invest. 71:1649-1660.

17. Meinkoth, J., and G. Wahl. 1984. Hybridization of nucleic acids immobilized on solid supports. Anal. Biochem. 138:267-284.

18. Pelham, H. R., and R. J. Jackson. 1976. An efficient mRNAdependent translation system from reticulocyte lysates. Eur. J. Biochem. 67:247-256.

19. Omary, M. B., and I. S. Trowbridge. 1981. Biosynthesis of the human transferrin receptor in cultured cells. J. Biol. Chem. 256:1288812892.

20. Laemmli, U. K. 1970. Cleavage of structural proteins during the assembly of the head of bacteriophage T4. Nature (Lond.). 227:680-685.

21. Romeo, P. H., A. Dubart, B. Grandchamp, H. de Verneuil, J. Rosa, Y. Nordmann, and M. Goossens. 1984. Isolation and identification of a cDNA clone coding for rat uroporphyrinogen decarboxylase. Proc. Natl. Acad. Sci. USA. 81:3346-3350.
22. Wilson, J. M., B. W. Baugher, P. M. Mattes, P. E. Daddona, and W. N. Kelley. 1982. Titration of human hypoxanthine-guanine phosphoribosyltransferase. J. Clin. Invest. 69:706-715.

23. Valerio, D., M. G. Duyvesteyn, H. Van Ormondt, P. Meera Khan, and A. J. van der Eb. 1984. Adenosine deaminase deficiency in cells derived from humans with severe combined immunodeficiency is due to an aberration of the ADA protein. Nucleic Acids Res. 12:10151024.

24. Daddona, P. E., B. L. Davidson, J. L. Perignon, and W. N. Kelley. 1985. Genetic expression in partial adenosine deaminase deficiency. $J$. Biol. Chem. 260:3875-3880.

25. White, R. L. 1984. DNA in medicine. Human genetics. Lancet. ii: $1257-1262$.

26. Pirastu, M., L. del Sonno, F. Conconi, C. Vullo, and Y. W. Kan. 1984. Ferrara $\beta^{\circ}$ thalassemia caused by the $B^{39}$ nonsense mutation. Nature (Lond.). 307:76.

27. Kidd, V. J., M. S. Golbus, R. B. Wallace, K. Itakura, and S. L. Woo. 1984. Prenatal diagnosis of 1 -antitrypsin deficiency by direct analysis of the mutation site in the gene. Nature (Lond.). 310:639-642. 